\title{
Policies that Succeed and Programs that Fail? Ambiguity, Conflict, and Crisis in Greek Higher Education
}

\author{
Nikolaos Zahariadis, University of Alabama at Birmingham \\ and Theofanis Exadaktylos, University of Surrey
}

\begin{abstract}
Why do some policies adopted by a wide margin fail to be implemented? Highlighting the role of policy entrepreneurial strategies within the Multiple Streams Approach (MSA), we examine the implementation of Greek higher education reform in 2011 to argue that when policies adversely affect the status quo, successful entrepreneurial strategies of issuelinkage and framing, side payments, and institutional rule manipulation are more likely to lead to implementation failure under conditions of crisis, centralized monopoly, and inconsistent political communication. The findings clarify MSA by specifying the conditions that increase the coupling strategies' chances of success or failure and illuminate the role ambiguity and conflict play in policy reform and implementation.
\end{abstract}

Paper prepared for presentation at the biennial meeting of the European Studies Association, Boston, March 4-7, 2015. An earlier version was presented at the workshop on "Ambiguity and Public Policy," University of Alabama at Birmingham, Birmingham, AL, November 14-15, 2014. The authors thank Harald Sætren and workshop participants for valuable comments and suggestions. 
Why do some policies adopted by wide margins fail to be implemented? Highlighting the role of policy entrepreneurial strategies within the Multiple Streams Approach (MSA) (Kingdon, 1995; Zahariadis, 2014), we explore the implementation of Greek higher education reform to probe the following hypothesis: when policies adversely affect the status quo, successful strategies of policy formation (agenda-setting and policy adoption) are more likely to lead to implementation failure under conditions of crisis, centralized monopoly, and inconsistent political communication. In MSA terms, the mechanisms of failure include decoupling problems from solutions, undermining support in the political stream, and altering estimates of equity and efficiency in the policy stream. We define failure as inability or unwillingness to execute the law in letter or spirit within the legally prescribed time frame. Within our empirical case, the policy has not completely failed, but major aspects of it have been dramatically modified, delayed, or abandoned.

It is expected policies attracting extensive public and political support should be implemented with relatively few obstacles. Wide appeal is likely to overcome impediments to execution because both the public and politicians have come to a consensus. We examine one exception: the law reforming Greek higher education in 2011 passed by more than two-thirds majority of votes in Parliament (260 out of 300 , or 87 percent). This feat is remarkable given that it was passed by a greater majority of votes than any other bill since the restoration of Greek democracy in 1974. It is also the only time when the parliamentary groups of both major parties, the socialist PASOK and the conservative New Democracy, in their entirety voted for a law of any kind. Yet, implementation proved significantly more difficult.

The importance of our case rests on two reasons. First, higher education reform was not included in the reforms agreed in Greece's bailout packages; yet it has assumed significant 
public attention and has raised considerable political conflict. Governing parties and the opposition have used education reform as rallying cry and "battlefield" to support or oppose the bailout packages and fight broader struggles regarding the role of the public sector in Greece (Diamantopoulou, 2011; Tsiligiris, 2012). Second, the case enables our research design because it is precisely in circumstances of wide political agreement that we expect unproblematic implementation. In George and Bennett's (2005) terms, an extreme "most likely" case such as ours is best positioned to highlight problems because they are least expected. Being exemplar but temporally limited, the case is not representative of general policy change but of redistributive reforms under specific conditions. We unpack the paradox of failure by stressing the contingent nature of implementation strategies (Matland, 1995).

We chose MSA as our theoretical framework for two reasons. First, the case of reform is precisely the issue that MSA claims to be most applicable. Because reforms involve collections of problems, solutions, and dramatic shifts in values and institutional structures, there are likely to be high levels of ambiguity, political contestation, and downright ignorance between cause and effect (March \& Olsen, 1983; Rommetveit, 1976). Second, despite its applicability, MSA does not provide explicit mechanisms linking implementation and policy formation apart from general strategic effects of ambiguity (e.g., Baier, March \& Sætren, 1986; Zahariadis, 2008; but see Ridde, 2009).

Situating our analysis within MSA, we first discuss the role of policy entrepreneurs in bringing about policy change. Theoretical linkages between entrepreneurial strategies and implementation are then used to specify conditions of success (or failure). We don't argue strategies are the only factors affecting reform; we just explore their effects. Using Pollitt and Bouckaert's (2011, p. 77) reform typology, we empirically probe the hypothesis in four areas: 
financial, personnel, organizational, and performance measurement. The findings clarify MSA by specifying the conditions affecting the likelihood of success or failure and illustrate the role ambiguity and conflict play in linking policy formation to implementation.

Policy Entrepreneurs and Policy Change

Studies of the policy process often highlight the ability of policy entrepreneurs to build coalitions that enact and implement policy changes (e.g., Zahariadis, 2003; Mintrom, 2000). Entrepreneurs are individual or corporate actors who operate in or out of government and who are willing to spend resources - time, energy, expertise, or money - to influence policy outcomes. Mintrom and Norman (2009) argue that entrepreneurs continuously advocate and broker, lead, display social acuity, and mobilize in support or opposition to policy alternatives at any stage of the policy process. Analysis of entrepreneurial activity is normally divided in two parts: attributes and strategies. Most of the literature focuses on major attributes - access and persistence - that increase the chances of entrepreneurial success (Kingdon, 1995). However, success cannot be attributed solely to individual attributes; it must also be considered as strategy in context (Ackrill, Kay, \& Zahariadis, 2013). Relatively little work has been done to systematically explain the conditions under which entrepreneurial strategies may be successful. In one of the first studies of entrepreneurial strategies, Roberts and King (1991) suggest the following four comprehensive activities: creative/intellectual activities that highlight the importance of ideas and framing; strategic activities that stress the need to develop a vision and heuristics for action; mobilization and execution activities that highlight media attention and coalition-building; and administrative and evaluative activities that facilitate implementation. The authors posit success is a function of the ability to overcome resistance. The more radical the innovation, the greater the resistance and the more comprehensive strategies will be. Their work 
is interesting and informative but also limited not only to a specific kind of entrepreneur, one who operates outside government, but also to a specific kind of policy, innovation. Clearly, more specification and nuance are needed to make the argument more empirically useful.

Drawing conclusions from a comparative study of 15 cases of water management across different countries, Meijerink and Huitema (2010) differentiate between four types of entrepreneurial strategies: coalition building, idea development and dissemination, institutional manipulation (venue-shopping, complexity, and centralization), and strategic framing of ideas and opportunities. Although strategies may be pursued to support or block policy, policy entrepreneurs, the authors find, more often than not "create barriers to future change." Brouwer and Biermann (2011) add that policy entrepreneurs may pursue more than one strategy at the same time. However, both studies do not identify the conditions under which strategies may be successful or not. Zahariadis (2003) discusses conditions of success, but his work neither involves a systematic taxonomy nor is it linked to implementation.

In sum, the literature succinctly categorizes strategies, but it neither identifies conditions of success nor does it link strategy to implementation. The only exception is Roberts and King (1991), but their study is severely limited both in scope and content. Our study fills this gap. Multiple Streams, Implementation and Coalition-Building MSA places policy entrepreneurs and their strategies at the heart of policy change. It argues policies are made when entrepreneurs couple or join together three streams - problems, policies, and politics. The chances a particular policy will be adopted increase significantly when all three streams are coupled during open policy windows. Windows are opportunities that open in the problem or politics stream; they define and limit the context within which policy is made. We begin where this argument leaves off, namely by linking policy formation to 
implementation and by identifying conditions for entrepreneurial coupling success or failure. We conceptualize a nested policy system with policy windows opening sequentially (Howlett, McConnell, \& Perl, 2013). Whereas most MSA theorizing assumes a single window and ends analysis with a policy's adoption (or not), we view policy outputs as constituting implementation windows. We estimate two phases (formation and implementation) with multiple rounds of deliberation, each phase marked by continuities with previous actions but also adding new actors and/or potentially new resources (Teisman, 2000). We are not interested in how successful entrepreneurial strategies shape policy outputs but how they are used to implement them, connecting context and coalitions around linked but ambiguous frames of problems and solutions. Varying MSA's central notion of ambiguity we relax the assumption of independent problem and policy streams.

The main objective of policy entrepreneurs is to build coalitions, akin to Levin and Ferman's (1986) “fixers," which help them enact and implement their pet project (Mintrom, 2000). Applying Meijerink and Huitema's (2010) insight, we explore how coalitions are built using issue linkages and framing, institutional rule manipulation, and side payments. The latter is added as an important resource to create and maintain minimum winning coalitions (Riker, 1962). The very fact we conceptualize two phases implies coalitions that support a policy during the policy formation phase may be different from the ones that implement it.

The key difference between the two phases is that agencies and bureaucrats are intimately involved in implementation. In contrast to policy formation where politicians are the crucial decision makers, in implementation they often have a monitoring role. Fimister and Hill (1993) claim that leaders often prefer the legitimacy of initiating reforms while allowing agencies to edit or translate them to deflect blame from failure. Therefore, the composition of coalitions leads to 
different objectives and naturally different incentives to join and/or deliver public services. For example, whereas funding may (or not) be an issue in policy formation, adequate resources to implement a policy are one of the key ingredients in successfully translating talk into action (Zahariadis, 2008). When policy is heavily contested, politicians secure success by structuring access and providing resources. In the presence of ambiguous goals and policy conflict, bureaucrats and more broadly local coalitions acquire significant discretion in shaping the exact nature, quantity, and quality of public services (Lipsky, 2010; Matland, 1995, p. 168).

\section{Entrepreneurial Strategy and Implementation Failure}

Under what conditions will resistance succeed in undermining the implementation success of coupling strategies? Using MSA logic, we hypothesize conditions of crisis, centralized monopoly, and inconsistent political communication increase the chances of failure by decoupling problems from solutions, undermining support in the politics stream, and altering estimates of equity and efficiency in the policy stream.

Ambiguity is often essential because disparate coalitions need to be built and supporters must declare victory, each perhaps for his/her own reasons. This ambiguity provides room for interpretation to those who must put laws into practice, leading to contingent strategies of implementation (Matland, 1995). When ambiguity is low with bitter conflict over goals, compliance is contested and outcomes determined by political power. When ambiguity is high and conflict equally high, the strength of local coalitions shapes the outcome. Matland labels the former political implementation and the latter symbolic implementation. Strategy success is therefore likely to vary because reforms, being redistributive policies, generate conflict and often ambiguity.

H1: When policies adversely affect the status quo, successful entrepreneurial strategies of issue- 
linkage and framing, side payments, and institutional rule manipulation are more likely to lead to implementation failure under conditions of crisis, centralized monopoly, and inconsistent political communication.

Government bureaucracies are by nature change-avoiding organizations (Wilson, 1989). Change involves redistribution of resources, subtraction, or addition of responsibilities, creating uncertainty over future outcomes. For example, creating new universities may generate animosity by existing institutions if new universities are viewed as taking resources away from established ones. The same is true when new policies create jurisdictional ambiguities or overlap which in turn lead to the development of new rules, diverse preferences, unstable practices, turf battles, and potentially new conceptions of political legitimacy and consequences (Hajer, 2003; Olsen, 2006). Because government bureaucracies, especially universities, are complex organizations with numerous and often ill-defined goals, they are likely to resist implementing new policies that adversely affect their budgets or structure. The greater the ambiguity of the enacted law, the more intense resistance is likely to be because of potential consequences (Huber \& Shipan, 2002).

Reforms frequently involve framing contests (Boin, 't Hart, \& McConnell, 2009) and contradictory demands. The last factor is especially troubling in periods of crisis because policy makers are pushed by forces to adopt policies that return some semblance of normalcy and pulled by others to reform in order to address the conditions that created the crisis in the first place (Zahariadis, 2013). Because crises involve significant turbulence and uncertainty, they create demands for fundamental changes. When these demands become ambiguous laws, resistance to programmatic change stiffens because autonomous agents and/or clients usually do not participate in the decision-making process. Therefore, issue linkages that are successful in 
creating minimum winning coalitions are likely to inhibit implementation. For example, making the argument that a severe fiscal crisis necessitates dramatic funding cuts stiffens resistance because such a linkage helps opponents to also put forth broader grievances about the crisis to undermine reforms. Problems and solutions are decoupled and likely adversely reframed to protract conflict. The end result is spillover across issues and policy sectors, resulting in symbolic efforts to legitimize responses that are likely to falter under the weight of increased political conflict. In the presence of ambiguity and conflict the larger the coalition during policy formation under crisis conditions, the stiffer the resistance will be during implementation because the higher number of affected actors will increase the number of associated grievances. In implementation, the policy stays the same but problems are reframed because "actors see their interests tied to a specific policy definition" (Matland, 1995, p. 168). Side payments are more difficult to offer because of budgetary constraints. While side payments, such as extra funding or more rights, are needed to maintain the stability of minimum winning coalitions (Riker, 1962), the activation of new actors during implementation might prove prohibitive during fiscal crises. Reforms may still be passed, but their likelihood of implementation decreases significantly.

Centralization and enforcement sanctions in case of non-compliance greatly affect civil servant resistance (Saurugger, 2012). While centralized monopolies at first glance confer enforcement benefits to elected representatives because of top-down hierarchy of funding and communication, they work the other way, too. Centralized monopolies also confer significant benefits to bureaucrats because of the lack of competition in delivering services and an appropriate regulatory framework. If the particular public service is considered to be socially and economically vital, such as higher education, monopolies operating as public goods empower administrators and educators to accrue benefits in spite of small budgets or adverse directives 
from above by way of trade-offs among conflicting goals (Shoenenberger, 2005). Power differentials privilege policy makers because they can issue directives and withhold funding if not implemented. However, the monopolistic nature of delivery implies that significant losses will accrue to both bureaucrats and politicians if resistance stiffens, i.e., it leads to strikes, legal challenges, and so on. Assuming no intervention by the courts, the institutional arena changes from a governmental hierarchy to a more fluid public arena where more and perhaps irrelevant actors, e.g., the media or unions, might tip the balance against the government, undermining support within the politics stream. Such non-legislative factors shape the probability of expected sanctions (Huber \& Shipan, 2002). Centralization makes it easier to identify culprits and creates bottlenecks that may stifle implementation. The more centralized the structure of delivery, the easier it is to launch legal and other challenges to bring the whole policy to a halt.

Finally, inconsistent political communication affects the intensity and outcome of reforms (Pollitt \& Bouckaert, 2011) because legal challenges and other delay tactics alter the sustainability and viability of coalitions. Indeed, Sætren (2009) finds leadership commitment and will to be key ingredients of entrepreneurial success in sustaining coalitions that promote radical reforms. Inconsistency prompts reframing, ambiguity, and conflicts because it signals lack of political will (Brinkerhoff, 2000). As actors become unable to predict outcomes, they are more likely to misrepresent information in pursuit of non-cooperative behavior (Robbins, 2010, p. 526). Inconsistency also affects perceived payoff. The payoff for joining a coalition is the expected value of future decisions multiplied by the probability of the coalition functioning (Gamson, 1961). If a steeper slope discounts the value of decisions because outcomes are pushed further into the future, coalition support may fall apart. Resources are redistributed but not in a predictably stable fashion, leading to even deeper utility discounts for supporters and potential 
benefits for opponents. In MSA terms, inconsistency fosters ambiguity and redistribution, which alter the estimates of equity and efficiency that sustained the policy's appeal in the first place (Zahariadis, 2014).

The fact that reforms take a long time to bear fruit saps political motivation and willingness to build long-term sustainable coalitions (Pollitt, 2008, pp. 16-20, 171). The idea is that civil servants can wait out their elected or appointed supervisors because they have tenure. Because of tenure, they are more likely to face long-term consequences and are therefore also more likely to resist implementing programs they perceive might adversely affect them. Besides, delays may also bring politicians to power who are more sympathetic to bureaucratic grievances. When policies are decoupled from their supporters in the politics stream, MSA contends, the likelihood of implementation failure increases. The longer the delays, the greater the likelihood will be that sympathetic policy makers might come to power and derail the "adverse" reform.

Data and Methods

Implementation success or failure is difficult to define and measure. Analysts use several definitions - efficiency, effectiveness, compliance, or accountability (e.g., Matland, 1995; Ingram \& Schneider, 1990; Zahariadis, 2008) - but the short time horizon of our case necessitates an output approach. We view it dichotomously: either the proposed changes have been implemented within the specified time period or not. This gives us two values, which we further break down by including the reasonable outcome of partial change. Partial change refers to variance either across units (some universities, for example, implement changes while others do not) or within unit (a university creates some novel institutional structures but not others) within the time frame of the law. Failure (no change) exists when changes are either not or partially implemented beyond the specified time frame. Success (change) exists when changes 
are either faithfully executed or when the majority of units or the majority of proposed changes in an area is implemented within the time frame of the law.

To gain analytical traction but still retain breadth and variance, we use Pollitt and Bouckaert's (2011) typology of reform content - finance, personnel, organization, and performance measurement. Our selection has the advantage of different outcomes, permitting incase variance and increasing degrees of freedom. We observe policies enacted by very high margins contain programs that may fail to be faithfully executed. We examine why by assuming the three entrepreneurial strategies (our independent variables) - issue-linkage and framing, side payments, and institutional rule manipulation - were used to enact Law 4009/2011 and assess how their deployment under contextual conditions affect implementation outcomes. Three conditions are specified. Crisis is defined as sharp fluctuation in output or employment. Real Greek economic output shrank by 25 percent in real terms since 2008 while unemployment peaked at 27 percent in 2013 (Zahariadis 2013). Higher education funding decreased by 22 percent in constant terms while faculty size shrank by 24.6 percent since 2007/08 (Elstat 2014). Centralization is defined as monopoly in funding or delivery. Article 16 of the Greek constitution proclaims higher education to be a state, tuition-free monopoly. Inconsistent political communication refers to laws, executive decisions, and ministerial proclamations that contradict the letter of the Law after its adoption.

Our time period begins in August 2011 when the law was passed and ends at the time of writing (October 2014). Evidence was gathered from 14 semi-structured interviews and rigorous analysis of legal, university, ministry, and other public documents. Interviewees included members of academic staff, former and current ministry officials, civil servants, and ordinary voters. Information was distilled from those sources and tabulated to multiply data sources and 
identify discrepancies (Yin, 2014). Evidence was then clustered into variables using frequency distributions and graphs to aid interpretation of results.

Implementing Law 4009/2011

We focus attention on Greek Law 4009, which was passed in 2011. Inspired by OECD (2011) advice and being remarkable in scope and political support, it created high expectations and optimism despite legislative flaws and ambiguities. By decoupling university administration from direct political influence; streamlining financial processes to increase transparency and accountability; extending decision-making autonomy based on individual institutional needs; and creating a system of evaluation and accreditation, the legislative framework set up by Law 4009/2011 intended to bring the quality of Greek universities closer to European and international standards. Clearly, the sheer range of enacted changes posed serious challenges. By examining implementation over time across four areas we can trace the process and identify sticky areas that have not progressed and areas that were reformed successfully.

Although passed by an unprecedented majority in Greek Parliament, the Law immediately faced resistance by university unions, rectors, and the youth organizations of political parties operating in universities because it shook up the status quo. Some of its clauses were even contested as unconstitutional before the Council of State. The government's response to implementation resistance has been to amend it twice since 2011 to accommodate some of the concerns raised by the stakeholders. Law 4076/2012 (Government Gazette, 159/A/2012), also known as Arvanitopoulos Law (after the name of the Education Minister at the time), amended articles dealing with the organizational structure of universities; the merging, closure and relocation of schools and departments based on demand; and election processes of University Councils members. Subsequently, the recent ministerial decision 140277/E5 published on 12 
September 2014 (Government Gazette 2435/B/2014) - also known as Loverdos Law (after the name of then Education Minister) - amended the clauses on student transfers between departments at different universities and on issues relating to student enrollment. Eight additional laws and one ministerial decision clarified, supplemented, and set up implementation.

\section{** Insert Table 1 here **}

Table 1 shows the planned action by year, size (distance from status quo), impact on endreceivers, and in bold italics highlights the outcomes. The timeframe for implementation was mostly not adhered. Whereas change took place in several areas, we observe that many programs were systematically delayed or abandoned, particularly those calling for structural changes in the operation of Greek universities. Amendments to the Law within the first six months from ratification and the change of government in June 2012 provided for additional space for resistance mechanisms and coalitions to develop in spillover fashion, illustrating elements of symbolic implementation. For example, one change that was later reversed centered on reconstituting departments as the basic academic units (the Law abolished them and created schools instead). The intent was to rationalize resources and avoid duplication, but under crisis conditions it was reframed by academics as prelude to layoffs (interview with faculty from a non-Greek university). Indeed, the quick change demonstrates in line with our expectations that crisis facilitates issue linkages and frames that undermine implementation. Overall, we find there is no relationship in terms of distance from the status quo, further reinforcing our argument that variation is an outcome of entrepreneurial strategies of different coalitions.

\section{Organization}

The original Law (4009/2011) had a clear framework of implementation which has now been extended due to resistance by the end-receivers of reforms. Amendments raised fresh issues 
and legal challenges. According to a member of the quality assessment team at Aristotle University of Thessaloniki, partial change is due to new conditions raised by the two amendments of the Law. The HQAA had been set up and running since 2008 based on a previous law from 2005 establishing the agency, but it is not at the heart of making education policy as the Law intended (interview with Greek university faculty). Interviewed staff from Democritus University of Thrace, whose department was to incorporate three more departments from other campuses stated the closure, merging, and relocation of departments has been mostly cancelled. Several interviewees confirmed that still pending court cases regarding student matters demonstrate the level of resistance to the status quo. More generally, the centralized nature of Greek higher education (Kyriazis \& Asderaki, 2008) assured that legal challenges caused a chain reaction of delays in implementation. For example, challenges to the constitutionality of new Councils on the basis of university self-governance meant elections for new rectors could not proceed because the law states only new Councils could propose rector candidates. Corroborating previous findings (e.g., Kavasakalis, 2013), there is widespread agreement among Greek academics on reform to escape the state stranglehold in higher education. The irony is opposing coalitions use the same distaste over centralization to both support the need for reform and oppose specific changes.

Our expectation that institutional rule manipulation in a centralized environment would lead to implementation failure is borne by the evidence. Centralization of Greek higher education ensured failure would spill over across institutions, with the biggest institutions taking the lead. The interviewee from Democritus University argued: "the setting up of new Councils at the National University of Athens, Aristotle University, and the Athens Polytechnic School were blocked by University administrations, often helped by student unions affiliated with political 
parties inside the Universities." It should be noted these three universities are the biggest (in terms of student enrollment) and most prestigious institutions in Greece. "At the same time, when new Councils were set up, student occupation of university buildings prevented the new bodies from performing their duties." In addition, inability to create new University Charters as envisioned by the Law (several were drafted but none was adopted by October 2014) has robbed proponents from securing potential benefits that could empower new internal constituencies.

The fact the Law was ratified with a large majority in Parliament did not guarantee success in the implementation phase. The new policy brought dramatic changes to the established state of play in Greek universities, which the government did not anticipate. For one, the winning coalitions between the two stages of the process were completely different. Different stakeholders coalesced against implementation, especially at the microlevel, partly because frequent changes at the helm of the Ministry of Education (there have been five ministers since January 2012) provided fodder to opponents with inconsistent messages. An interviewee conjectured that despite rhetoric to the contrary Ministers actually favor centralization and undermine their own reforms for political gain. Supporting the statement, a former university rector told us Greek politicians routinely undermined enacted changes for fear of losing political control, illustrating the symbolic elements of implementation. Politicians often lack the political will to mobilize support, sustain effort, or apply credible sanctions (Brinkerhoff, 2000) partly conditioned by electoral fortune. Besides, as March and Olsen (1983, p. 290) assert reforms symbolize the possibility of action and belief in "that possibility may be of greater [political] significance than the execution of it."

Seeking to bolster his/her legacy and political fortune, each minister reinterpreted the Law according to partisan criteria (Saiti, 2013, p. 6). For example, Giorgos Babiniotis, former 
rector of the National University, called the Law "unworkable" (Mavrogordatos, 2012) and decoupled funding from implementation by ruling within the first two weeks of his tenure as Minister of Education in 2012 that universities would be eligible for state funding without applying Law 4009 (Marseilles, 2012). Another, Andreas Loverdos (2014) who is also a law school professor, immediately after becoming Minister in June 2014 declared he was not bound by the education budget because he did not vote for it and went against government policy by refusing to lay off administrative staff. Corroborating our hypothesis the partial failure of implementation and considerable delays were due to inconsistent political messages delivered by those in charge.

Because no Councils were elected by the 2012 deadline except for one institution, the Ministry relented and gave extensions for the process to take place. Whereas originally the aim of Councils was to link universities to the broader social environment, rectors and students alike decoupled the solution (Council) from its problem (lack of embeddedness in social environment). Instead, they objected to "external," political as they called it, interference arguing for members to be internal academics because they knew local conditions (interview with faculty member in Athens; Mylopoulos, 2012). As a result, the majority of Council members are now internal; they elect the external minority (Art. 8, par. 5b as amended by 4076/2012).

Indeed, some professors and rectors viewed opposition as resistance to orders by foreign powers. Being part of a "broader neoliberal scheme" (e.g., Traianou 2013; Gouvias 2012) to introduce "direct privatization of public universities," Ioannis Mylopoulos (2012), then rector of Aristotle University, declared the Law to be "a witch-hunt" detrimental to the academy. In line with expectations, the broader crisis increased the chances of links among disparate issues. Leaving aside the fact that the Law did not call for the establishment of private universities, his 
argument is important largely for its political implications. The rector discounted the Law's legitimacy because it was the product of agreement, as he alleged, between the elites of three parties at the time (PASOK, New Democracy, and the right-wing LAOS) and did not adequately reflect the balance of forces in politics. The fact that his essay appeared in the newspaper of the main opposition party, the Radical Left (SYRIZA), clearly added a partisan dimension to his allegation. It took three years for these obstacles to be lifted and most universities have now elected Councils although the latter are involved in bitter turf battles with faculty senates over the limit and nature of Council oversight powers (interview with faculty member).

\section{Finance/Organization}

As passed, the law called for changes in administration (new rectors elected by newly constituted Councils) to be implemented by the academic year 2012/13, otherwise funding would be withdrawn. Under crisis conditions, our hypothesis predicts the strategy of side payments holding the policy adoption coalition together will likely fail in implementation. Clearly, the stick of withdrawing side payments that held the coalition together during adoption proved detrimental during implementation. Even faculty who supported the spirit of the law objected to what they perceived to be coercion because it did not exhibit "sensitivity to the democratic process of electing university leadership" (interview with faculty member of the Aristotle University). In fact, resistance was so strong that student unions held in some occasions members of the Council captive in their offices, threatening and harassing them if they took up their new duties as a sign of accepting the legitimacy of the Law (interview with affected member of the University of Macedonia). In addition, the conference of rectors demanded immediate restoration of public funding to higher education and decoupling of funding from the assessment exercise envisioned in the law (Mylopoulos, 2012). 
A thorny financial issue, the case of "eternal" registration of students, has been met with stiff resistance by student associations, political parties as well as Schools and Departments. The Law specified students enrolled in universities before 2003/04 had until September 2014 to complete their studies. As many interviewees concurred, opposition by rectors and students centered on the alleged unfairness of dropping students who could not attend classes due to financial exigencies caused by the crisis (Marseilles, 2014). Symbolically and conveniently missing was the fact that the de-enrollment provision was not new but first introduced in a 2007 law. Figures from the Ministry of Education show the number of inactive (so called eternal) students has risen steeply since 2004 long before the onset of the 2010 crisis (Elstat, 2014). Implementation clearly altered perceptions of equity in the policy stream.

Confirming our hypothesis, institutional changes led to stiff resistance, which the Ministry has attempted to assuage through side payments and institutional rule manipulation. The latest amendment to the Law by Minister Loverdos states 2014/15 is the last academic year when the system of eternal registration and non-merit based transfer of students is permissible.

\section{Personnel}

Regarding changes to promotion and ranks, the broader crisis helped link disparate issues, decoupling solutions from problems, reframing problems, intensifying policy conflict, and eventually undermining implementation (Saiti, 2013). The points validate the MSA view that policy-making involves complex interactions of heterogeneous problems and solutions. As reformers are hard-pressed to sustain political attention, "less central actors come to the forefront" (March and Olsen, 1983, p. 286). An interviewee from the National University of Athens who was recently appointed as Professor abroad emphasized strong reactions to rationalizing salary scales, altering promotion ranks, and forcing full professors to teach more 
classes were expressed by established interests inside the universities. He claimed the threatened legal action at the Council of State would postpone implementation of these articles too far into the future; so the Ministry decided to scrap it altogether. "Absenteeism from teaching is a perennial problem," explained political science professor George Mavrogordatos (2012), “but Greek professors are seldom, if ever, held accountable.” Another university interviewee informed he opposed the law because it did not curb enough the power of department chairs. It is obvious that coalitions of support or opposition to radical change are tenuously held together by contextual factors subject to fluid views of fairness and equity (Sætren, 2009). Confirming our expectation, crisis conditions facilitated issue-linkages and reframed problems increasing the chances of implementation failure.

\section{Performance Measurement}

Finally and confirming the counterfactual, while accreditation of Universities and validation of programs of study according to HQAA standards has been met with some resistance, there was little opposition to the general system of evaluating quality of studies and academic staff. When explained to students who attempted an intrusion to the process, a quality assurance team member told us, it was widely accepted as a worthy practice. Assessment pursued the spirit of broader European reforms to make Greek higher education more transparent, accountable, and outward looking (Asderaki, 2009). Political coercion worked because HQAA began work before the crisis erupted in 2010 (Papadimitriou, 2011) with supportive university coalitions already in place. Besides, the number of implementation decisions needing to be (re)negotiated was relatively small increasing the likelihood of implementation success (Pressman and Wildavsky, 1984). The 2011 law left little room for reframing and reinforced the same message by reiterating previously made linkages between 
funding and quality assurance, thereby sustaining the winning coalition during implementation.

\section{Conclusion}

Why do some policies adopted by a wide margin fail to be implemented? Emphasizing the role of policy entrepreneurial strategies in MSA, we have analyzed Greek higher education reforms to find when policies adversely affect the status quo successful entrepreneurial strategies of issue-linkage and framing, side payments, and institutional rule manipulation are more likely to lead to implementation failure under conditions of crisis, centralized monopoly, and inconsistent political communication. Although our study is temporally limited and needs empirical validation across more cases, the findings have preliminary implications for MSA and the study of implementation and policy reform.

While MSA assumes independent problem and policy streams, we began implementation analysis with closely linked streams and specified conditions that prompted de- and re-coupling. Institutional reforms often involve collision between internally generated processes of change and externally imposed ones (Olsen, 2007). The activation of a new set of actors during implementation - university administration, professors, and students (and through them political parties) - undermined the successful entrepreneurial coupling strategies of issue linking and framing during policy formation. Intense conflict and ambiguity helped decouple reforms from their problems and encouraged entrepreneurs to reframe reforms as an assault to the essence of the public sector in Greece (interview with university faculty member). Whereas the coalition built to adopt the law was purely political in demonstrating the strength of the government but also bringing forward other political forces for accountability purposes, the government monopolized implementation through bargaining and often coercion in top-down fashion (e.g., Van Meter and Van Horn, 1975) without building coalitions with the universities themselves. 
Inconsistent political messages amidst the broader financial crisis generated intense ambiguity and altered estimates of equity and efficiency. As a result, the same coupling strategies that worked well when applied to policy formation hindered implementation because the latter privileged a very different set of actors.

While implementation success is contingent, we observe what may be implementation drift. Whereas the literature divides implementation into distinct types with appropriate strategies (e.g., Matland, 1995), we find fluid boundaries and movement across types. Greek higher education reform had elements of both political (low ambiguity-high conflict) and symbolic (high ambiguity-high conflict) implementation. In some instances coercion failed (e.g., new University Councils in the first year of implementation or department closures) but in others it succeeded (e.g., HQAA). In all cases, local coalitions proved vital to success (or failure). We also observed over time a drift from political toward symbolic implementation. Inability (or unwillingness) to succeed not only exacerbated policy conflict over time but also signaled opportunities to reframe problems and abandon adopted solutions. The resultant ambiguity empowered local coalitions to demand further modifications hoping new macrolevel participants in the politics stream would legitimize them.

Finally, our findings help explain why there is so much movement in policy reform but relatively little movement forward. Brunsson (1989) describes two distinct spheres to explain organizational behavior: talk (policy formation in our case) and action (implementation). $\mathrm{He}$ shows when organizations face problematic environmental demands they decouple talk from action to contain political conflict and still produce actionable results. Our findings validate and amend his argument. We, too, attribute the paradox of wide agreement and little implementation to the interaction between diverse coalitions during policy formation and implementation. We 
further specify, however, that under conditions of crisis, centralization, and inconsistent political messages, interaction breaks down, ambiguity increases, and conflict spills over from policy formation to implementation. Spillover effects occur not only in agenda-setting, as MSA predicts, but also in implementation through the mechanism of activating new actors whose actions refract the effectiveness of coupling strategies. Whereas power is given to implementation agents to buffer policy from political friction during the formation stage, the same power undermines implementation success. Political conflict spreads to implementation so that there is continuity in discontinuity. There is ambiguity and perennial change in the form of new laws passed but very little new happening. MSA shows that failure is sometimes not the consequence of contentious decisions but the cause of poorly implemented but widely agreed upon choices. 


\section{References}

Ackrill, Robert, Adrian Kay, and Nikolaos Zahariadis. 2013. "Multiple Streams and the EU Policy Process.” Journal of European Public Policy 20 (6): 871-887.

Asderaki, Foteini. 2009. "The Impact of the Bologna Process on the Development of the Greek Quality Assurance System.” Quality in Higher Education 15 (2): 105-122.

Baier, Vicki E., James G. March, and Harald Sætren. 1986. "Implementation and Ambiguity." Scandinavian Journal of Management Studies 2 (3-4): 197-212.

Brinkerhoff, Derick W. 2000. “Assessing Political Will for Anti-corruption Efforts: An Analytic Framework." Public Administration and Development 20: 239-252.

Boin, Arjen, Paul 't Hart, and Allan McConnell. 2009. “Crisis Exploitation: Political and Policy Impacts of Framing Contests.” Journal of European Public Policy 16 (1): 81-106.

Brunsson, Nils. 1989. The Organization of Hypocrisy: Talk, Decisions, and Actions in Organizations. New York: Wiley.

Brouwer, Stijn, and Frank Biermann. 2011. “Towards Adaptive management: Examining the Strategies of Policy Entrepreneurs in Dutch Water Management.” Ecology and Society 16 (4): 5. Accessed August 10, 2014 from http://dx.doi.org/10.5751/ES-04315-160405.

Diamantopoulou, Anna. 2011. “Anna Diamantopoulou : The Role of Education in Greece’s Economic Recovery.” 2011 Public Lecture at the London School of Economics. Accessed August 15, 2014 from http://www.lse.ac.uk/europeanInstitute/research/hellenicObservatory/Events/pubLectures /Diamantopoulou 2011.aspx.

Elstat. (2014). “Tertiary Education” (in Greek). Accessed August 1, 2014 from http://www.statistics.gr/portal/page/portal/ESYE/PAGE-themes?p_param=A1403. 
Fimister, Geoff, and Michael Hill. 1993. "Delegating Implementation Problems: Social Security, Housing and Community Care in Britain.” In Michael Hill (ed.), New Agendas in the Study of the Policy Process (110-129). Hemel Hempstead: Harvester Wheatsheaf.

Gamson, William A. 1961. “A Theory of Coalition Formation.” American Sociological Review 26 (3): $373-382$.

George, Alexander L., and Andrew Bennett. 2005. Case Studies and Theory Development in the Social Sciences. Cambridge, MA: The MIT Press.

Gouvias, Dionyssios. 2012. “The Post-Modern Rhetoric of Recent Reforms in Greek Higher Education.” Journal for Critical Education Policy Studies 10 (2): 282-313.

Hajer, Maarten. 2003. "Policy without Polity? Policy Analysis and the Institutional Void." Policy Sciences 36: 175-195.

Howlett, Michael, Allan McConnell, and Anthony Perl. 2013. "Stages, Cycles, Soups, Streams and Windows: Reconciling Mixed Metaphors of the Policy Process.” Paper presented at ECPR $41^{\text {St }}$ Joint Sessions, Workshop on Decision-Making under Ambiguity and Time Constraints: Assessing the Multiple Streams Framework. Mainz, Germany, March 11-16. Huber, John D., and Charles R. Shipan. 2002. Deliberate Discretion? The Institutional Foundations of Bureaucratic Autonomy. New York: Cambridge University Press.

Ingram, Helen, and Anne Schneider. 1990. "Improving Implementation through Framing Smarter Statutes.” Journal of Public Policy 10 (1): 67-88.

Kavasakalis, Aggelos. 2013. "Are Common Beliefs Present among Greek Academics during the Implementation of a Controversial University Policy?" International Research in Education 1 (1): 5-28.

Kingdon, John W. 1995. Agendas, Alternatives, and Public Policies. $2^{\text {nd }}$ ed. New York: Harper 
Collins.

Kyriazis, Athanasios, and Foteini Asderaki. 2008. Higher Education in Greece. Bucharest: UNESCO-CEPES.

Levin, Martin, and Barbara Ferman. 1986. "The Political Hand: Policy Implementation and Youth Employment Programs.” Journal of Policy Analysis and Management 5 (2): 311325.

Lipsky, Michael. 2010. Street-Level Bureaucracy. Expanded ed. New York: Russell Sage Foundation.

Loverdos, Andreas. 2014. "Loverdos: I Cannot Implement a Budget I have Voted against." To Vima (in Greek). June 17. Accessed October 10, 2014 from http://www.tovima.gr/vimafm/interviews/article/?aid=606743.

March, James G., and Johan P. Olsen. 1983. “Organizing Political Life: What Administrative Reorganization Tells us about Government.” American Political Science Review 77: 281297.

Marseilles, Makki. 2014. “'Stagnant' Students to be Struck off Enrolment Register.” University World News, August 29. Accessed November 6, 2014 from http://www.universityworldnews.com/article.php?story=20140828170855934.

Marseilles, Makki. 2012. "Universities Face Huge Losses to Reserves after Bond 'Haircut'.” University World News, April 2. Accessed October 10, 2014 from http://www.universityworldnews.com/article.php?story=20120402213156178.

Matland, Richard E. 1995. "Synthesizing the Implementation Literature: The Ambiguity-Conflict Model of Policy Implementation." Journal of Public Administration Research and Theory 5 (2): 145-174. 
Mavrogordatos, George T. 2012. "Styx and Stones.” Times Higher Education, May 24. Accessed November 15, 2014 at http://www.timeshighereducation.co.uk/features/styx-andstones/420077.article.

Meijerink, Sander, \& Dave Huitema. 2010. "Policy Entrepreneurs and Change Strategies: Lessons from Sixteen Case Studies of Water Transitions Around the Globe.” Ecology and Society 15 (2): 21. Accessed August 10, 2014 from http://www.ecologyandsociety.org/vol15/iss2/art21/.

Mintrom, Michael. 2000. Policy Entrepreneurs and School Choice. Washington, DC: Georgetown University Press.

Mintrom, Michael, and Phillipa Norman. 2009. "Policy Entrepreneurship and Policy Change." Policy Studies Journal 37: 649-667.

Mylopoulos, Ioannis. 2012. "6+1 Changes to Restore Democratic Legitimacy and the Functioning of the Academy" (in Greek). July 22. Accessed August 15, 2014 from http://mylopoulos.gr/node/481.

Olsen, Johan P. 2006. "Maybe it's Time to Rediscover Bureaucracy.” Journal of Public Administration Theory and Practice 16 (1): 1-24. . 2007. "The Institutional Dynamics of the European University." In Peter Maassen and Johan P. Olsen (eds.), University Dynamics and European Integration (pp. 25-54). Dordrecht: Springer.

Organization for Economic Cooperation and Development (OECD). 2011. Successful Performers and Successful Reformers in Education: Education Policy Advice for Greece. Paris: OECD.

Papadimitriou, Antigoni. 2011. "Reforms, Leadership and Quality Management in Greek Higher 
Education.” Tertiary Education and Management 17 (4): 355-372.

Pollitt, Christopher. 2008. Time, Policy, Management: Governing with the Past. Oxford: Oxford University Press.

Pollitt, Christopher, and Geert Bouckaert. 2011. Public Management Reform: A Comparative Analysis - New Public Management, Governance, and the Neo-Weberian State. $3^{\text {rd }}$ ed. Oxford: Oxford University Press.

Pressman, Jeffrey L., and Aaron Wildavsky. 1984. Implementation. 3rd ed. Berkeley: University of California Press.

Roberts, Nancy C., and Paula J. King. 1991. "Policy Entrepreneurs: Their Activity Structure and Function in the Policy Process." Journal of Public Administration Research and Theory 1 (2): $147-175$.

Robbins, Suzanne M. 2010. "Play Nice or Pick a Fight? Cooperation as an Interest Group Strategy at Implementation.” Policy Studies Journal 38 (3): 515-535.

Ridde, Valéry. 2009. "Policy Implementation in an African State: An Extension of Kingdon's Multiple Streams Approach.” Public Administration 87 (4): 938-954.

Riker, William H. 1962. The Theory of Political Coalitions. New Haven: Yale University Press. Rommetveit, Kåre. 1976. “Decision Making under Changing Norms.” In James G. March and Johan P. Olsen, Ambiguity and Choice in Organizations (pp. 140-155). Bergen, Norway: Universitetforlaget.

Sætren, Harald. (2009). "Explaining Radical Policy Change against all Odds: The Role of Leadership, Institutions, Program Design and Policy Windows.” In Jeffrey A. Raffel, Peter Leisink, and Anthony E. Middlebrooks (eds.), Public Sector Leadership: International Challenges and Perspectives (53-72). Cheltenham, UK: Edward Elgar. 
Saiti, Anna. 2013. "Reforms in Greek Education 1991 -2011: Reforms or Something Else?" EJournal of Education Policy (Spring): 1-10.

Saurugger, Sabine. 2012. "Beyond Non-Compliance with Legal Norms." In Theofanis

Exadaktylos and Claudio Radaelli (eds.), Research Design in European Studies (pp. 105124). New York: Palgrave Macmillan.

Schoenenberger, Alain M. 2005. "Are Higher Education and Academic Research a Public Good or a Public Responsibility? A Review of the Economic Literature." In Luc Weber and Sjur Bergan (eds.), The Public Responsibility for Higher Education and Research (pp. 45-94). Strasbourg: Council of Europe.

Teisman, Geert R. 2000. "Models for Research into Decision-Making Processes: On Phases, Streams and Decision-Making Rounds.” Public Administration 78 (4): 937-956.

Traianou, Anna. 2013. “Greek Education Reform: Resistance and Despair.” In Ken Jones (ed.), Education and Europe: The Politics of Austerity (pp. 86- 112). London: Radicaledbooks. Tsiligiris, Vangelis. 2012. “Grexit: Another Lost Opportunity for Greek Higher Education?" University World News, June 3. Accessed October 10, 2014 from http://www.universityworldnews.com/article.php?story=20120530125539702.

Van Meter, Donald S., and Carl E. Van Horn. 1975. "The Policy Implementation Process: A Conceptual Framework." Administration and Society 6 (4): 445-488.

Wilson, James Q. 1989. Bureaucracy. New York: Basic Books.

Yin, Robert K. 2014. Case Study Research: Design and Methods. $5^{\text {th }}$ ed. Thousand Oaks, CA: Sage.

Zahariadis, Nikolaos. 2003. Ambiguity and Choice in Public Policy. Washington, DC: Georgetown University Press. 
. 2008. "Europeanization as Program Implementation: Effective and Democratic?" Journal of Comparative Policy Analysis 10 (3): 221-238.

. 2013. "Leading Reform amidst Transboundary Crises: Lessons from Greece." Public

Administration 91 (3): 648-662.

. 2014. "Ambiguity and Multiple Streams." In Paul A. Sabatier and Christopher M. Weible (eds.), Theories of the Policy Process, $3^{\text {rd }}$ ed. Boulder, CO: Westview Press. 
Table 1

Actions and Implementation Timeframe with State of Play

\begin{tabular}{|c|c|c|c|c|}
\hline $\begin{array}{l}\text { Content/Size/ } \\
\text { Impact }\end{array}$ & 2011 & 2012 & 2013 & 2014-16 \\
\hline $\begin{array}{l}\text { ORGANIZATION } \\
\text { Establish University } \\
\text { Councils } \\
\text { - Major reform } \\
\text { - High impact }\end{array}$ & $\begin{array}{l}\text { - } \begin{array}{c}\text { Election } \\
\text { procedures }\end{array} \\
\text { NO CHANGE } \\
\text { - Process stalled } \\
\text { due to reactions } \\
\text { from University } \\
\text { administrations }\end{array}$ & $\begin{array}{ll}\text { - } & \begin{array}{l}\text { Elect President } \\
\text { and Members } \\
\text { of Council }\end{array} \\
\text { - } \quad \text { Elect } & \text { Chancellors } \\
\text { - } \quad \text { Organize } \\
\text { Faculties } \\
\text { - } \quad \text { Elect Deans } \\
\text { - Constitution } \\
\text { into a body } \\
\text { PARTIAL } \\
\text { CHANGE } \\
\text {-Changes stopped } \\
\text { due to } \\
\text { amendments in } \\
\text { Law }\end{array}$ & $\begin{array}{l}\text { - } \begin{array}{l}\text { Merger and } \\
\text { closure of } \\
\text { departments }\end{array} \\
\text { NO CHANGE } \\
\text { - Scrapped }\end{array}$ & $\begin{array}{l}\text { PARTIAL } \\
\text { CHANGE } \\
\text { - New Councils } \\
\text { in place in many } \\
\text { institutions } \\
\text { (announced in } \\
\text { September 2014) }\end{array}$ \\
\hline $\begin{array}{l}\text { ORGANIZATION } \\
\text { Create } \\
\text { Organizational } \\
\text { Framework of } \\
\text { Autonomy for } \\
\text { Universities } \\
\text { - Major reform } \\
\text { • Medium-High } \\
\text { impact }\end{array}$ & $\begin{array}{l}\text { - } \begin{array}{l}\text { Set up } \\
\text { organizational } \\
\text { framework }\end{array} \\
\text { CHANGE } \\
\text { - Organizational } \\
\text { framework put in } \\
\text { place but not } \\
\text { enacted until } \\
2013\end{array}$ & $\begin{array}{l}\text { - } \begin{array}{l}\text { Set up internal } \\
\text { regulations }\end{array} \\
\text { - } \quad \begin{array}{l}\text { Submit } \\
\text { internal } \\
\text { regulations to } \\
\text { the Ministry }\end{array} \\
\text { NO CHANGE } \\
\text { - Stalled due to } \\
\text { the amendments } \\
\text { to the Law }\end{array}$ & $\begin{array}{ll}\text { - } & \text { Publish } \\
\text { frameworks in } \\
\text { Government } \\
\text { Gazette } \\
\text { (enactment) } \\
\text { - } \begin{array}{l}\text { Publish internal } \\
\text { regulations in }\end{array} \\
\text { Government } \\
\text { Gazette } \\
\text { (enactment) } \\
\text { PARTIAL } \\
\text { CHANGE } \\
\text { - Delayed }\end{array}$ & $\begin{array}{l}\text { CHANGE } \\
\text { - Published in } \\
\text { July } 2014\end{array}$ \\
\hline $\begin{array}{l}\text { PERFORMANCE } \\
\text { Evaluation and } \\
\text { Transparency } \\
\text { - Major reform } \\
\text { - Medium-High } \\
\text { impact }\end{array}$ & 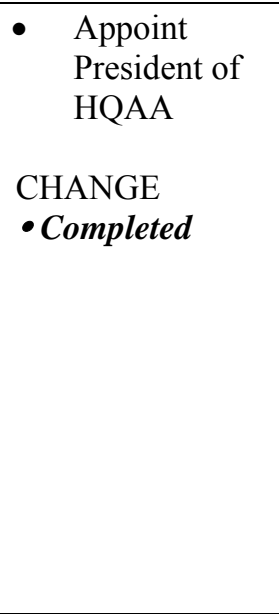 & $\begin{array}{ll}\text { - } & \text { Appoint } \\
\text { HQAA } \\
\text { members } \\
\text { Appoint } \\
\text { HQAA } \\
\text { Director } \\
\text { General } \\
\text { - } & \text { Publication of } \\
\text { University } \\
\text { Quality } \\
\text { Assurance } \\
\text { Internal } \\
\text { Structures } \\
\text { HQAA } \\
\text { Charter }\end{array}$ & $\begin{array}{l}\text { CHANGE } \\
\text { - Initial evaluation } \\
\text { of Greek } \\
\text { Universities } \\
\text { completed with } \\
\text { some delay by } \\
2013-2014\end{array}$ & $\begin{array}{l}\text { CHANGE } \\
\text { •Accreditation } \\
\text { and validation } \\
\text { processes } \\
\text { scheduled to be } \\
\text { completed on } \\
\text { time }\end{array}$ \\
\hline
\end{tabular}




\begin{tabular}{|c|c|c|c|c|}
\hline & & $\begin{array}{l}\text { CHANGE } \\
\text { - Completed }\end{array}$ & & \\
\hline $\begin{array}{l}\text { PERSONNEL/ } \\
\text { FINANCE } \\
\text { Academic Staff } \\
\text { - Major reform } \\
\text { - High impact }\end{array}$ & & 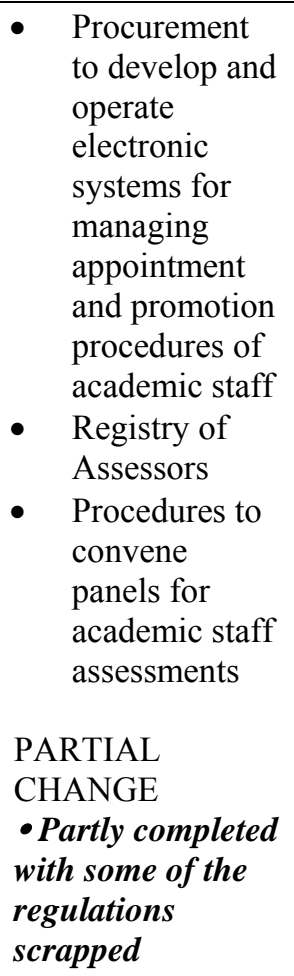 & 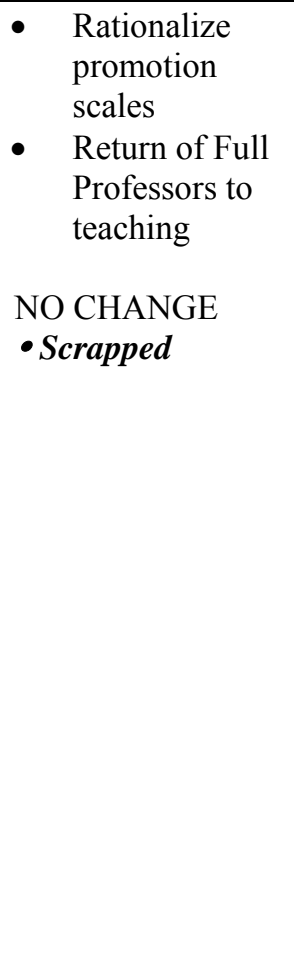 & \\
\hline $\begin{array}{l}\text { PERSONNEL/ } \\
\text { FINANCE } \\
\text { Administrative Staff } \\
\text { - Major reform } \\
\text { - High impact }\end{array}$ & & $\begin{array}{l}\text { - } \begin{array}{l}\text { Salary and } \\
\text { rank scales for } \\
\text { administrative } \\
\text { staff }\end{array} \\
\text { CHANGE } \\
\text { - Completed albeit } \\
\text { with some delay in } \\
2013\end{array}$ & & $\begin{array}{l}\text { - } \quad \text { Select new } \\
\text { University } \\
\quad \text { Secretariats } \\
\text { CHANGE } \\
\text { - Administrative } \\
\text { restructuring } \\
\text { took place with } \\
\text { some delay in } \\
2014\end{array}$ \\
\hline $\begin{array}{l}\text { ORGANIZATION } \\
\text { Programs of Study } \\
\text { • Minor reform } \\
\text { • Medium impact }\end{array}$ & $\begin{array}{l}\text { Issue vacation } \\
\text { time for } \\
\text { working } \\
\text { students } \\
\text { CHANGE } \\
\text { - Completed }\end{array}$ & $\begin{array}{l}\text { - } \begin{array}{l}\text { Procurement } \\
\text { for electronic } \\
\text { books and } \\
\text { virtual } \\
\text { learning } \\
\text { environments }\end{array} \\
\text { CHANGE } \\
\text { Completed and } \\
\text { scheduled for } \\
\text { implementation in } \\
\text { 2015/16 }\end{array}$ & 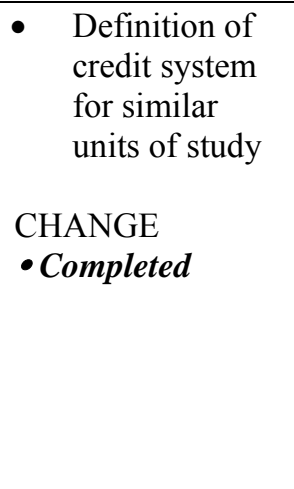 & \\
\hline ORGANIZATION & & $\begin{array}{ll}\text { - } & \text { Set up } \\
& \text { Councils for }\end{array}$ & $\begin{array}{ll}\text { - } & \begin{array}{l}\text { Establish upper } \\
\text { registration }\end{array}\end{array}$ & $\begin{array}{l}\text { CHANGE? } \\
\text { • Issue of }\end{array}$ \\
\hline
\end{tabular}




\begin{tabular}{|c|c|c|c|}
\hline $\begin{array}{l}\text { Student Matters } \\
\text { - Major reform } \\
\text { - High impact }\end{array}$ & $\begin{array}{l}\text { Student } \\
\text { Welfare } \\
\text { - Set Student } \\
\text { Welfare } \\
\text { Officers } \\
\text { (Ombudsman } \\
\text { Offices) } \\
\text { - Establish } \\
\text { Teaching } \\
\text { Support } \\
\text { Offices } \\
\text { - Establish } \\
\text { Student } \\
\text { Support } \\
\text { Services } \\
\text { Draft clauses } \\
\text { for student } \\
\text { loans } \\
\\
\text { NO CHANGE? } \\
\text { - State of play } \\
\text { unknown }\end{array}$ & $\begin{array}{l}\begin{array}{c}\text { limits and } \\
\text { deregister } \\
\text { "eternal" } \\
\text { students }\end{array} \\
\text { NO CHANGE } \\
\text { - Frozen for this } \\
\text { academic year }\end{array}$ & $\begin{array}{l}\text { eternal students } \\
\text { resolved; } \\
\text { implementation } \\
\text { will commence } \\
\text { in academic } \\
\text { year 2015/16 }\end{array}$ \\
\hline $\begin{array}{l}\text { ORGANIZATION } \\
\text { National Strategy } \\
\text { for Higher } \\
\text { Education - } \\
\text { Program Design } \\
\text { Agreements } \\
\text { - Medium reform } \\
\text { - High impact }\end{array}$ & 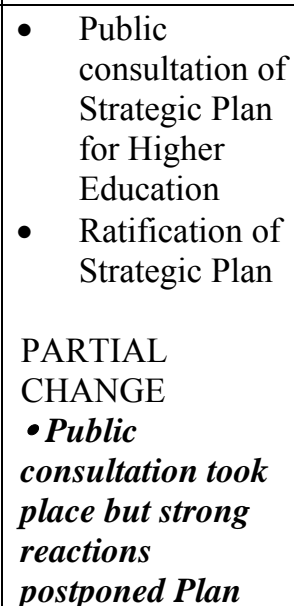 & $\begin{array}{l}\text { Ratify Program } \\
\text { Design } \\
\text { Agreements } \\
\text { 2013-14 } \\
\text { NO CHANGE } \\
\text { - Postponed to } \\
2014\end{array}$ & 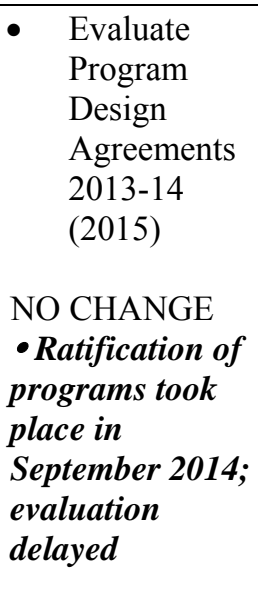 \\
\hline $\begin{array}{l}\text { ORGANIZATION } \\
\text { Research Centers of } \\
\text { Excellence } \\
\text { - Major reform } \\
\text { - Medium impact }\end{array}$ & 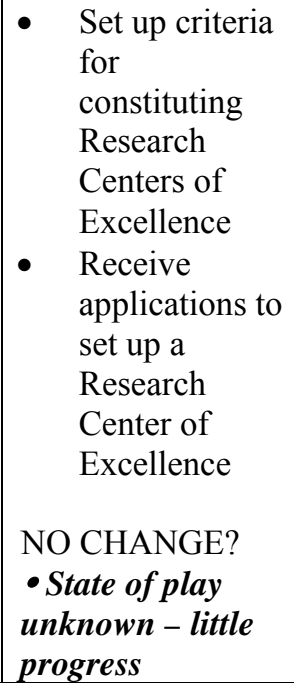 & & \\
\hline
\end{tabular}




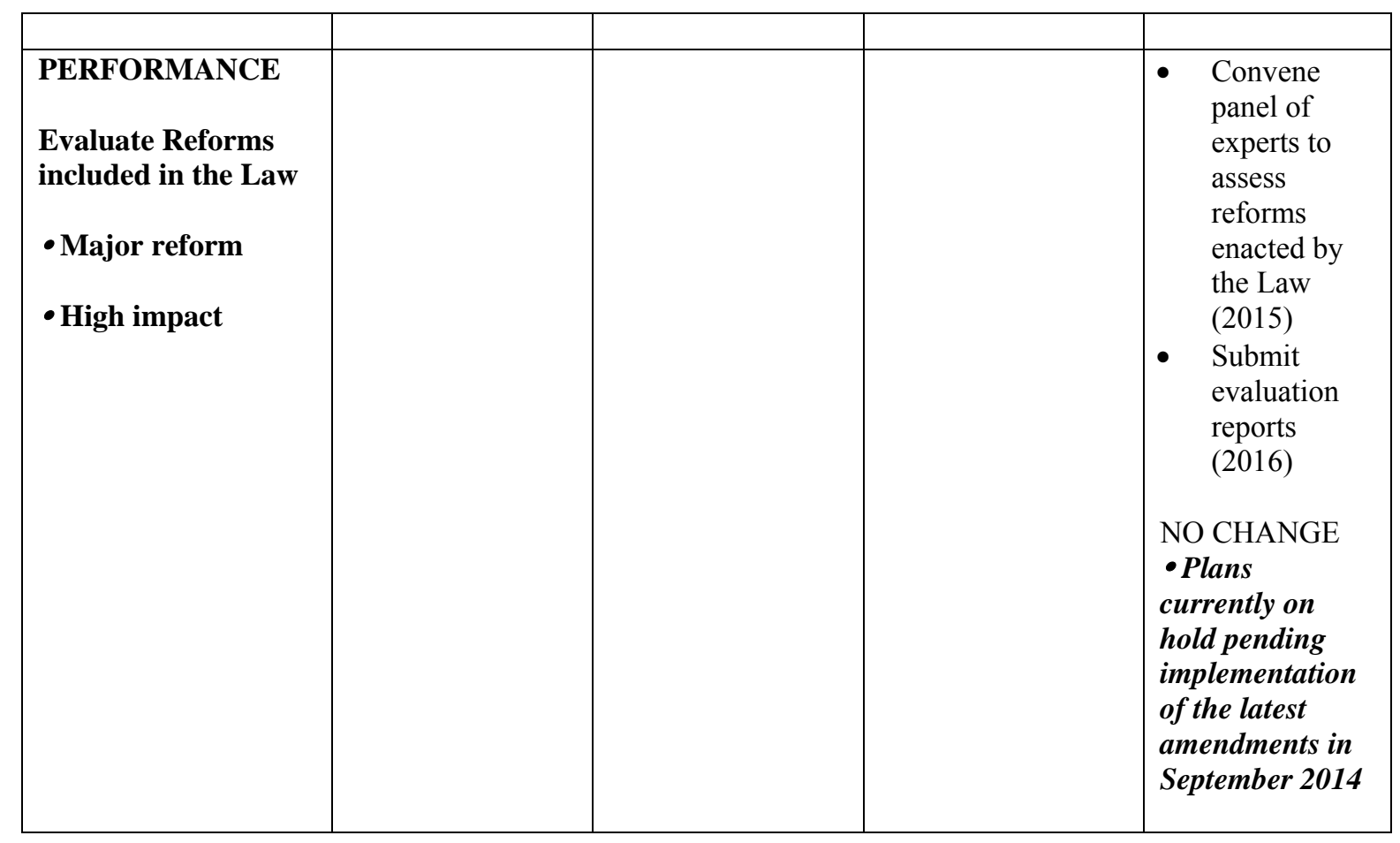

Source: Interviews, public consultation outcomes, Government Gazette (2014) 